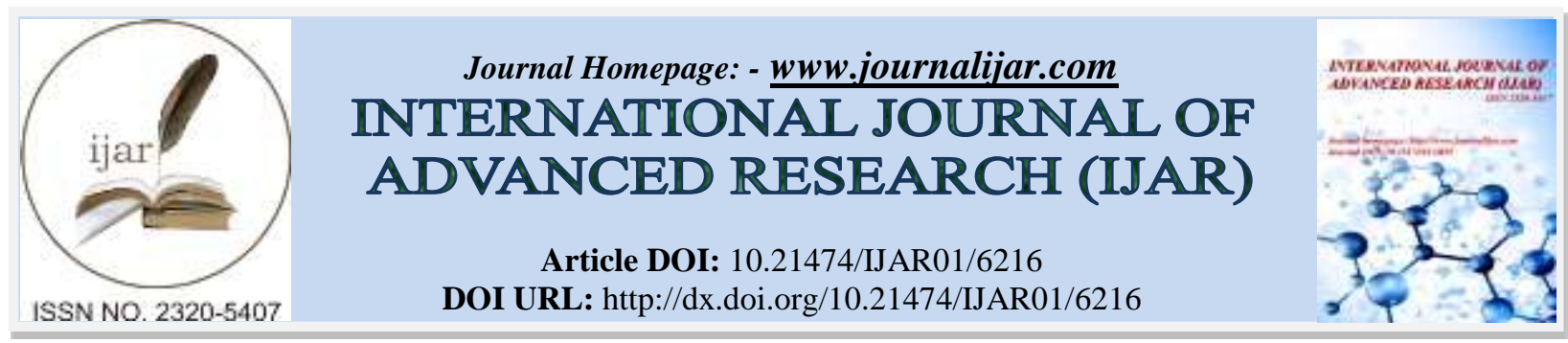

RESEARCH ARTICLE

\title{
MANAGEMENT OF PERIPARTUM DEPRESSION: BETTER, PREVENT THAN TREAT!.
}

\section{Suresh Kumar' ${ }^{1}$ and Laxminarayana Kurady Bairy ${ }^{2}$.}

1. Assistant Professor, Department of Pharmacology, RAK College of Medical Sciences, RAK Medical and Health Sciences University, P.O.Box No.11172, Ras Al Khaimah, UAE.

2. Professor and Chairperson, Department of Pharmacology, RAK College of Medical Sciences, RAK Medical and Health Sciences University, P.O.Box No.11172, Ras Al Khaimah, UAE.

\section{Manuscript Info}

\section{Manuscript History}

Received: 05 November 2017

Final Accepted: 07 December 2017

Published: January 2018

Keywords:-

Peripartum, Depression, Psychotherapy.

\section{Abstract}

Peripartum depression is one of the common mental illness affecting significant population during that period. The disease morbidity not only affects mother but also baby and spouse. Thus adequate management of this condition, has huge positive impact on the whole family.

Treatment and prevention are the two dimensions of managing the ailment. Medications and psychological interventions are being used for both treatment and prevention. Selective serotonin reuptake inhibitors (SSRIs) especially sertraline are the common drugs utilized for treatment. Similarly, estrogens have shown some evidence of efficacy. Though, SSRIs are recommended during peripartum period, psychotherapy which is equally effective holds significance due to its safety profile. Psychological intervention includes psychosocial community-based intervention, cognitive behavioral therapy (CBT), interpersonal therapy (IPT). Exercise and yoga have also shown to be useful for peripartum depression. Saffron and light therapy seems to be of promise which needs to be further explored.

Preventive strategies are proved to be effective in managing peripartum depression especially psychological interventions. The American College of Obstetrics and Gynecology (ACOG) and American Academy of Pediatrics (AAP) recommends screening for depression and identifying "at risk mothers". Thus prevention of peripartum depression has to be part of optimal antenatal care. The psychological interventions being both safe and effective seems to be the ideal to be used in this setting. Among drugs only sertraline has been shown to be good in preventing episodes of depression. Hence, "prevention is better than treatment" holds good for peripartum depression especially by psychological interventions. The available evidence for treatment and prevention of peripartum depression is overviewed in this review. 


\section{Introduction:-}

Depression disorder with peripartum onset is a major mental health illness all over the world. Recently, the definition of depression in post-partum phase has been widened (Jeste A 2013). Psychiatry's Diagnostic and Statistical Manual (DSM V) published in 2013 defines post-partum depression as "most recent episode of major depression if onset of mood symptoms occurs during pregnancy or in the 4 weeks following delivery" thus including "peripartum onset" as specifier. Though many studies have included 1-year post-partum to define post-partum depression, the current DSM V restricts the definition to include symptoms onset within 4 weeks after delivery.

Major depression disorder (MMD) with peripartum onset as per DSM V is estimated to be 3\% to 6\%. (Jeste A 2013). However, several studies have pointed out that this could be much higher. One meta-analysis estimated perinatal depression in 3 months window to be $19.2 \%$ and more narrowly defined MDD estimated at $7.1 \%$ of new mothers (Gavin et al 2005). It is also evident that antenatal depression may be a strong predictor of post-natal depression and both occur at similar rates (O'Hara and Gorman 2004)). Further, around 2.3\% and 4.3\% of fathers experience antenatal and post-natal depression respectively especially if they felt stressed or in poor health (Underwood et al 2017).

In United Arab Emirates, the prevalence of post-partum depression is reported to be $23 \%$ at 3 months of postnatal and at 6 months this fell to $12.5 \%$. The risk factors associated comprised of not breastfeeding, giving birth to the first child, poor self-body image and view of weight, poor relationship with mother-in-law, and an older age at marriage (Green et al 2006).

Post-partum depression (PPD) state poses challenge not only on the mother but also on newborn growth and development. The systematic review and meta-analysis showed association of untreated antenatal depression with preterm birth and low birth weight (Jarde et al 2016). The prime therapeutic options and preventive impact of peripartum depression is narrated in this review.

\section{Etiology and risk factors:-}

Genetic predisposition to PPD has been evaluated and the study infers that serotonin gene polymorphisms are associated with depression. Similarly, vitamin D has also been attributed to occurrence of depression. Nutritional status such as iron deficiency is also associated with post-partum depression. Pathogenesis of peripartum depression is correlated with hormonal and physiological changes involving HPA axis occurring during pregnancy and after childbirth. The study noted that sudden withdrawal of hormones would trigger mood disturbance in women with previous history of postpartum depression (Bloch et al 2000). The exaggerated postpartum hypothalamic-pituitaryadrenal refractory period, due to placental corticotrophin releasing hormone is also hypothesized with depression (Glynn et al 2013). Similarly, interaction between estrogen and serotonergic pathway is documented, providing scientific plausibility for the use of estrogen in treatment of postpartum depression. The study also found that postsynaptic 5HT1A receptor binding is decreased in postpartum depression (Moses-Kolko et al 2008)

Physiological changes during pregnancy is often attributed for occurrence of post-partum depression (Glynn et al 2013). There is evidence that hormonal changes and differing gene expression of $H P 1 B P 3$ and TTC $9 B$ would predict the occurrence of post-partum depression (Osborne et al 2016). This study also delineates the differences between PPD and antenatal depression continuing after childbirth. Further, a study has suggested "hormone sensitive postpartum depression" to be a subgroup who are sensitive to hormonal changes of childbirth (Schiller et al 2015).

\section{Therapeutic options available:-}

The management of perinatal depression involves treatment and prevention of depression episodes. The studies often consider both late pregnancy depression and post-natal depression together. The available therapeutic options are detailed below, followed by preventive strategies.

\section{Selective serotonin reuptake inhibitors (SSRI):-}

To date only SSRI have been of little success in treating PPD. A meta-analysis found that SSRI are not superior but efficacious and safe when compared to other modalities of treatment including cognitive behavioral intervention (De Crescenzo et al 2014). However, this systematic review, which included 6 trials and 596 participants, also found that the evidence is insufficient for antidepressants or psychological/psychosocial treatments being effective. Further, the study was inconclusive about comparative effectiveness and tolerability of different antidepressants. Another systematic review also documented that clinical studies in post-partum depression are of high heterogeneity. The 
study emphasized need for robust larger clinical trials given that serotonergic and hormones hold preliminary promise as pharmacotherapy ( $\mathrm{Ng}$ et al 2010). With the dearth of well-conducted larger randomized controlled trials, prescribers treating post-partum depression are left with drawing evidences, from trials among general adult population and observational studies. The importance of individualizing therapy in postpartum depression is suggested by a review and expert opinion (di Scalea and Wisner 2009).

As per the safety of SSRIs is concerned the recent meta-analysis which evaluated risk of congenital heart disease with use of SSRI in first trimester of pregnancy found no association with it (Wang et al 2015). Another study evaluated association of SSRIs with risk of postpartum hemorrhage and found no association between them (Kim et al 2016). Currently, it is recommended that women should be encouraged to breast feed while being treated with antidepressants (Kim et al 2014). A systematic review assessing prenatal antidepressant exposure and neurodevelopment in infants concluded that most of the studies showed no difference between those exposed to antidepressants and those who are not. However, two studies revealed significant differences in motor function in the new born. The studies included were of high heterogeneity, making the conclusion not definitive (Gentile et al 2011).

Sertraline in combination with brief dynamic psychotherapy was not better than placebo combined with psychotherapy in causing significant remission in therapeutic randomized controlled trial (Bloch et al 2012).Fluoxetine along with counselling was found to be effective in reducing depression levels when compared with placebo (Appleby et al 1997). Nevertheless, patients receiving 6 sessions of counselling improved most in the study. Similarly, paroxetine was evaluated in an 8 weeks randomized controlled trial against placebo. This study also showed better remission rate with paroxetine (Yonkers et al 2008). However, most of these studies involved sample size of less than 100 indicating reliability to be obtained from larger randomized controlled trials.

\section{Estrogens:-}

The evidence for efficacy for estradiol in postpartum depression was given by the study, which evaluated transdermal estradiol, with added cyclical dydrogesterone in last 3 months of 6 months therapy. The study showed that remission rate is much higher in estradiol group as compared to placebo (Gregoire et al 1996). However the sample size in each arm was small with 34 in active group and 27 in placebo group.

Another, open-label trial of sublingual 17ß-estradiol in 23 severe postpartum depression mothers achieved remission after 2 weeks. However, antidepressant use by most of these women proved to be a confounder for the results (Ahokas et al 2001). Recent attempt to study estradiol in postpartum depression was by a randomized trial with transdermal estrogen. The trial was stopped due to lower serum concentration of estrogen achieved by transdermal estradiol patches used (Wisner et al 2015). Thus, the benefit of estrogen is still not completely proved which mandates a larger randomized controlled trial.

\section{Psychosocial community-based intervention:-}

Another crucial study involving 230 post-natal mothers demonstrated in a randomized controlled trial, that multicomponent intervention such as psychoeducational group, treatment adherence support, and pharmacotherapy (if needed) was better than usual care normally available in the clinics, including antidepressant drugs, brief psychotherapeutic interventions, medical consultations, or external referral for specialty treatment. This study showed a mean Edinburgh Postnatal Depression Scale (EPDS) score drop of 4.5 at three months as compared to baseline (Rojas et al 2007). The effect continued even after 6 months though difference in improvement reduced among groups. The interesting part of the study is that number of mothers taking antidepressants also reduced in multicomponent intervention group as compared to usual care group.

A systematic review evaluating home based intervention as treatment reported statistically significant effect on postpartum depression (Leis et al 2009). Group treatment is showed to be promising in treating postpartum depression by another systematic review (Goodman et al 2011) (Table 1)

\section{Cognitive behavioural therapy:-}

A recent systematic review, which included forty studies, has found that cognitive behavioral therapy (CBT) is effective in preventing and treating perinatal depression. Further, the review elicited that both preventive and treatment interventions were effective during post-partum period than those initiated during pregnancy (Sockol 2015). Another systematic review evaluated the evidence for Neonatal Intensive Care Unit (NICU) based 
interventions in depression and anxiety. The study elicited that combined interventions had greatest positive impact on depressive symptoms (Mendleson et al 2017).

Cognitive behavioural therapy is further supported by another systematic review, which evaluated 8 randomized controlled trials. The study found that therapist-supported internet based CBT significantly improved stress, anxiety, and depressive symptoms among postpartum women (Lau et al 2017).

\section{Interpersonal therapy:-}

Interpersonal therapy (IPT), which involves dynamically informed and present-focused psychotherapy is also widely used for treating postpartum depression. A recent meta-analysis of studies exploring role of IPT in postpartum depression concluded that it has clinical benefit as both treatment and preventive measure (Miniati et al 2013).

\section{Exercise and Yoga}

Light to moderate exercise was shown to be of moderate effect on depressive symptoms in post-partum depression as concluded by a systematic review. Further, the study found that exercise also impacts with small benefit in preventing depression (McCurdy et al 2017). The Yoga intervention, which includes 16 classes over 8 weeks significantly improved depression in a randomized controlled trial among post-partum women (Buttner et al 2013). Further, Yoga is also perceived as being therapeutically beneficial in antenatal depression (Kinser and Masho 2015)).

\section{Other complementary agents: available evidence:-}

\section{Omega-3 fatty acids:-}

Many studies have explored the efficacy of omega 3 fatty acid in treatment and prevention of postpartum depression (Mozurkewich et al 2013, Makrides et al 2012). The randomized controlled trial evaluated eicosapentaenoic acid (EPA) and docosahexaenoic acid (DHA) for 8 weeks as treatment for postpartum depression. The study found no difference between test and control groups (Freeman et al 2008).

Similarly Makrides et al. evaluated DHA therapy as preventive strategy for depression starting from $21^{\text {st }}$ week of pregnancy to 6 months postpartum (Makrides et al 2012). This study also did not reveal any significant results between active and placebo groups. In a multi-arm preventive trial by Mozurkewich et al. DHA was compared with, higher dose EPA and, lower dose EPA starting from 12-20 weeks of pregnancy through upto 8 months postpartum. Even this study did not reveal any statistically significant results (Mozurkewich et al 2013).

\section{Saffron:-}

A preliminary study of 6-week, double-blind, randomized clinical trial in women aged 18-45 years with mild to moderate postpartum depression with Hamilton Depression Rating Scale (HDRS 17-item) score $\leq 18$ was conducted. The study showed that saffron (15mg) twice daily was able to achieve complete response in $40.6 \%$ as opposed to $50 \%$ in fluoxetine $(20 \mathrm{mg}$ ) twice-daily group (Kashani et al 2017) indicating saffron may be beneficial in this scenario.

\section{Light therapy:-}

The light therapy being useful for depression is scientifically plausible. However, very few studies have evaluated light therapy in perinatal depression. The evidence is good for light therapy in antenatal depression (Wirz-Justice et al 2011). Bright white fluorescent light of 7,000 lux given daily for 5 weeks was effective in improving, both Hamilton Depression Rating Scale (HDRS) with Atypical Depression Supplement (SIGH-ADS) in twenty-seven pregnant women with non-seasonal major depressive disorder.

However, another small 6-weeks trial with bright light (10,000 lux) among post-partum women did not show any statistical difference as compared with red dim light. The sample size was only 10 in bright light group and 5 in red dim light group (Corral et al 2007).

\section{Prevention:-}

There is good evidence to suggest preventive intervention for post-partum depression. The systematic review has analyzed twenty-eight trials, involving almost 17,000 women and concluded that psychosocial and psychological interventions would effectively prevent post-partum episodes of depression. The interventions included provision of intensive, professionally based postpartum home visits, telephone-based peer support, and interpersonal 
psychotherapy (Dennis and Dowswell 2013). The American College of Obstetrics and Gynecology (ACOG) recommends routine screening of perinatal women for depression (Stuart-Parrigon 2014). Similarly, American Academy of Pediatrics (AAP) recommends that all postpartum mothers be screened by pediatricians for depression (Earls 2010). Cochrane systematic review has evaluated the preventive strategies to avoid occurrence of post-partum depression. The review also provides evidence for identifying mothers "at risk" to optimize preventive strategies (Dennis and Dowswell 2013) [Table 2].

Psychological preventive interventions to reduce symptoms and occurrence of postpartum depression was evaluated by a meta-analysis. The study included of 37 randomized or quasi-randomized controlled trials and found the interventions to be effective at 6 months post-partum (Sockol et al 2013). A similar qualitative review inferred that interpersonal therapy (IPT) targeting "at risk" population is promising in preventing postpartum depression (Werner et al 2015).

Among pharmacological treatments, only sertraline has been proved drug in preventing the episodes of post-partum depression in a preventive trial and being recommended. (Wisner et al 2001, Kim et al 2014). In another randomized controlled trial, aiming at preventing postpartum depression after childbirth, progesterone was given intramuscularly within 48 hrs. of child birth and compared with placebo. The study found increased depressive episodes in test group at $6^{\text {th }}$ week and no difference at $12^{\text {th }}$ week post-partum (Lawrie et al 1998).

The possible benefits of dietary supplements such as omega-3 fatty acids, iron, folate, s-adenosyl-L-methionine, cobalamin, pyridoxine, riboflavin, vitamin D and calcium in preventing PPD were analysed by the systematic review (Miller et al 2013). The review concludes that there is no evidence to recommend any of these for preventing post-partum depression. However, a recent randomized controlled trial showed that 2000 IU vitamin D3 daily during late pregnancy (26 to 28 weeks) was effective in reducing perinatal depression levels as evaluated by Edinburgh Postnatal Depression scale even upto 8 weeks after child birth (Vaziri et al 2016). This study indicates preventive effect of vitamin $\mathrm{D}$ in perinatal depression with 78 in vitamin $\mathrm{D}$ group and 75 subjects in placebo group.

\section{Summary:-}

The current literature suggests equal evidence for both antidepressants and psychotherapy interventions for treating postpartum depression. The studies commonly includes postnatal depression are numerous, but there is severe dearth of well-conducted, larger randomized controlled trials. Pregnancy being special population, robust RCTs would be difficult to conduct. Thus, therapeutics of antenatal depression are based from RCTs of post-partum subjects, anecdotes and observational studies. SSRIs are recommended for treatment of depression during post-natal periods, which is backed by smaller randomized controlled trials. The pharmacological agents for treatment of perinatal depression mainly involves SSRIs, and estrogens. Sertraline is well recommended among SSRIs. Further, the treatment should always be individualized as suggested by di Scalea TL et al. [14] The evidence for use psychological interventions, as treatment of post-natal depression is also good.

Studies exploring preventive potential, commonly also aim therapeutic potential. The data is again sparse with preventive strategies. However, psychological interventions have evidence for being used to prevent occurrence of depression in perinatal period especially intensive-professionally based postpartum home visits, telephone-based peer support, and interpersonal psychotherapy. Among SSRIs, sertraline is shown to be effective in preventing episodes of depression by a small-randomized control trial. Psychological interventions designed to address "at risk" mothers have more apt evidence for prevention of peripartum depression. (Table 3)

Table 1:- Summary of important reviews on management of postpartum depression

\begin{tabular}{|l|l|l|l|l|}
\hline Therapy & Type & Studies included & Conclusion & Authors \\
\hline $\begin{array}{l}\text { Pharmacological } \\
\text { agents }\end{array}$ & $\begin{array}{l}\text { Review with } \\
\text { expert opinion }\end{array}$ & $\begin{array}{l}\text { 6 on treatment } \\
\text { and 5 on prevention }\end{array}$ & $\begin{array}{l}\text { Lack of data; SSRIs should be } \\
\text { considered first line }\end{array}$ & $\begin{array}{l}\text { Kim DR et al. } \\
2014\end{array}$ \\
\hline $\begin{array}{l}\text { Pharmacological } \\
\text { agents }\end{array}$ & $\begin{array}{l}\text { Review with } \\
\text { expert opinion }\end{array}$ & $\begin{array}{l}\text { 12 on treatment and } \\
\text { 7 on prevention of } \\
\text { PPD }\end{array}$ & $\begin{array}{l}\text { Selection of the specific } \\
\text { antidepressant should be } \\
\text { individualized }\end{array}$ & $\begin{array}{l}\text { di Scalea TL et } \\
\text { al. 2009 }\end{array}$ \\
\hline SSRIs & $\begin{array}{l}\text { Systematic } \\
\text { review }\end{array}$ & $\begin{array}{l}\text { Six randomized } \\
\text { clinical trials }\end{array}$ & $\begin{array}{l}\text { SSRIs are efficacious and well } \\
\text { tolerated but the clear } \\
\text { superiority over other } \\
\text { treatments is not established }\end{array}$ & $\begin{array}{l}\text { De Crescenzo F } \\
\text { et al. 2014 }\end{array}$ \\
\hline
\end{tabular}




\begin{tabular}{|c|c|c|c|c|}
\hline $\begin{array}{l}\text { Pharmacological } \\
\text { treatment }\end{array}$ & $\begin{array}{l}\text { Systematic } \\
\text { review }\end{array}$ & Fourteen studies & $\begin{array}{l}\text { Preliminary evidence in the } \\
\text { effectiveness seen for } \\
\text { serotonergic antidepressants } \\
\text { and hormones }\end{array}$ & Ng RC. 2010 \\
\hline $\begin{array}{l}\text { Home-based } \\
\text { psychological } \\
\text { interventions }\end{array}$ & $\begin{array}{l}\text { Systematic } \\
\text { review }\end{array}$ & $\begin{array}{l}\text { Five studies } \\
\text { assessing } \\
\text { treatments for PPD } \\
\text { and one assessing a } \\
\text { prevention }\end{array}$ & $\begin{array}{l}\text { Four studies reported } \\
\text { statistically significant effect on } \\
\text { postpartum depression }\end{array}$ & $\begin{array}{l}\text { Leis JA et al. } \\
2009\end{array}$ \\
\hline $\begin{array}{l}\text { Group treatment for } \\
\text { post-partum } \\
\text { depression }\end{array}$ & $\begin{array}{l}\text { Systematic } \\
\text { review }\end{array}$ & $\begin{array}{l}6 \text { randomized } \\
\text { controlled trials and } \\
5 \text { nonrandomized } \\
\text { studies }\end{array}$ & $\begin{array}{l}\text { Significant improvement in } \\
\text { depression scores }\end{array}$ & $\begin{array}{l}\text { Goodman JH, et } \\
\text { al. } 2011\end{array}$ \\
\hline $\begin{array}{l}\text { Efficacy of } \\
\text { Cognitive } \\
\text { behavioral therapy } \\
\text { (CBT) for treating } \\
\text { and } \\
\text { preventing } \\
\text { depression in } \\
\text { perinatal women }\end{array}$ & $\begin{array}{l}\text { Systematic } \\
\text { review }\end{array}$ & $\begin{array}{l}\text { Forty randomized } \\
\text { and quasi- } \\
\text { randomized } \\
\text { controlled trials }\end{array}$ & $\begin{array}{l}\text { strong evidence that CBT } \\
\text { interventions are effective for } \\
\text { treating and preventing } \\
\text { depression during the perinatal } \\
\text { period }\end{array}$ & Sockol LE 2015 \\
\hline $\begin{array}{l}\text { NICU-based } \\
\text { interventions }\end{array}$ & $\begin{array}{l}\text { Systematic } \\
\text { review and } \\
\text { meta-analysis }\end{array}$ & $\begin{array}{l}7 \text { eligible studies } \\
\text { assessing } \\
\text { depressive } \\
\text { symptoms } \\
\end{array}$ & $\begin{array}{l}\text { The evidence is strongest for } \\
\text { cognitive behavioral therapy } \\
\text { interventions on maternal } \\
\text { depressive symptoms. }\end{array}$ & $\begin{array}{l}\text { Mendelson T et } \\
\text { al. } 2017\end{array}$ \\
\hline $\begin{array}{l}\text { Therapist-supported } \\
\text { iCBT }\end{array}$ & $\begin{array}{l}\text { Systematic } \\
\text { Review and } \\
\text { Meta-Analysis }\end{array}$ & $\begin{array}{l}8 \text { randomized } \\
\text { controlled trials } \\
\text { were selected, } \\
\text { involving } 1523 \\
\text { participants }\end{array}$ & $\begin{array}{l}\text { Therapist-supported iCBT } \\
\text { significantly improves stress, } \\
\text { anxiety, and depressive } \\
\text { symptoms among postpartum } \\
\text { women }\end{array}$ & Lau Y et al. 2017 \\
\hline $\begin{array}{l}\text { Interpersonal } \\
\text { therapy (IPT) } \\
\text { (dynamically } \\
\text { informed and } \\
\text { present-focused } \\
\text { psychotherapy) }\end{array}$ & $\begin{array}{l}\text { Systematic } \\
\text { review }\end{array}$ & $\begin{array}{l}11 \text { clinical primary } \\
\text { trials assessing the } \\
\text { efficacy of IPT } \\
6 \text { studies with IPT } \\
\text { preventive } \\
\text { measures during } \\
\text { pregnancy }\end{array}$ & $\begin{array}{l}\text { IPT improves and prolongs } \\
\text { time of clinical remission }\end{array}$ & $\begin{array}{l}\text { Miniati M et al. } \\
2014\end{array}$ \\
\hline Exercise & Meta-analysis & $\begin{array}{l}10 \text { treatment trials, } \\
\text { six prevention trials } \\
16 \text { trials }\end{array}$ & $\begin{array}{l}\text { Light-to-moderate intensity } \\
\text { aerobic exercise has moderate } \\
\text { positive effect on depressive } \\
\text { symptoms and small positive } \\
\text { effect in prevention. }\end{array}$ & $\begin{array}{l}\text { McCurdy AP et } \\
\text { al. } 2017\end{array}$ \\
\hline
\end{tabular}

Table 2:- Prime reviews on preventive strategies for postpartum depression

\begin{tabular}{|l|l|l|l|l|}
\hline Drug /intervention & $\begin{array}{l}\text { Review } \\
\text { type }\end{array}$ & Studies & Outcome References \\
\hline $\begin{array}{l}\text { Existing approaches for } \\
\text { preventing postpartum } \\
\text { depression }\end{array}$ & $\begin{array}{l}\text { qualitative } \\
\text { review }\end{array}$ & $\begin{array}{l}\text { Eight RCTs of } \\
\text { biological } \\
\text { interventions were } \\
\text { identified and 37 } \\
\text { RCTs of psychological } \\
\text { or } \\
\text { psychosocial } \\
\text { interventions. }\end{array}$ & $\begin{array}{l}\text { Interpersonal therapy } \\
\text { targeting at risk } \\
\text { population is promising }\end{array}$ & Werner E et al. 2015 \\
& & & \\
\hline
\end{tabular}




\begin{tabular}{|c|c|c|c|c|}
\hline $\begin{array}{l}\text { Varied psychosocial and } \\
\text { psychological } \\
\text { interventions during } \\
\text { antepartum, intrapartum, } \\
\text { or postpartum compared } \\
\text { with usual care to reduce } \\
\text { the risk of developing } \\
\text { postpartum depression }\end{array}$ & $\begin{array}{l}\text { Systematic } \\
\text { review }\end{array}$ & Twenty-eight trials & $\begin{array}{l}\text { Interventions such as } \\
\text { provision of intensive, } \\
\text { professionally based } \\
\text { postpartum home visits, } \\
\text { telephone-based peer } \\
\text { support, } \\
\text { interpersonal } \\
\text { psychotherapy } \\
\text { significantly reduce } \\
\begin{array}{l}\text { depression } \\
\end{array}\end{array}$ & $\begin{array}{llll}\text { Dennis } & \text { CL } & \text { et } & \text { al. } \\
2013 & & & \end{array}$ \\
\hline $\begin{array}{l}\text { Preventive interventions } \\
\text { designed to decrease the } \\
\text { postpartum depressive } \\
\text { symptoms or decrease the } \\
\text { prevalence }\end{array}$ & $\begin{array}{l}\text { Meta- } \\
\text { analysis }\end{array}$ & $\begin{array}{l}37 \text { randomized } \\
\text { quasi-randomized } \\
\text { controlled trials }\end{array}$ & $\begin{array}{l}\text { Interventions } \\
\text { effectively decrease } \\
\text { postpartum depressive } \\
\text { symptoms by } 6 \text { months } \\
\text { and decrease risk of } \\
\text { occurrence }\end{array}$ & $\begin{array}{l}\text { Sockol LE et al. } \\
2013\end{array}$ \\
\hline
\end{tabular}

Table 3:- Summary of existing management options of perinatal depression

\begin{tabular}{|l|l|l|}
\hline Treatment & Antenatal depression & Post-natal depression \\
\hline Prevention & $\begin{array}{l}\text { Sparse data available } \\
\text { Evidence for psychological } \\
\text { intervention }\end{array}$ & Good evidence for psychological interventions \\
\hline
\end{tabular}

\section{References:-}

1. Ahokas A, Kaukoranta J, Wahlbeck K, Aito M.(2001) Estrogen deficiency in severe postpartum depression: successful treatment with sublingual physiologic 17 beta-estradiol: a preliminary study. J Clin Psychiatry., 62:332-6.

2. Appleby L, Warner R, Whitton A, Faragher B.(1997) A controlled study of fluoxetine and cognitivebehavioural counselling in the treatment of postnatal depression. BMJ., 314:932-6.

3. Bloch M, Schmidt PJ, Danaceau M, Murphy J, Nieman L, Rubinow DR.(2000) Effects of gonadal steroids in women with a history of postpartum depression. Am J Psychiatry., 157:924-30.

4. Bloch M, Meiboom H, Lorberblatt M, Bluvstein I, Aharonov I, Schreiber S.(2012) The effect of sertraline addon to brief dynamic psychotherapy for the treatment of postpartum depression: a randomized, double-blind, placebo-controlled study. J Clin Psychiatry., 73:235-41.

5. Buttner MM, Brock RL, O'Hara MW, Stuart S. (2015) Efficacy of yoga for depressed postpartum women: A randomized controlled trial. Complement Ther Clin Pract., 21:94-100.

6. Corral M, Wardrop AA, Zhang H, Grewal AK, Patton S.(2007) Morning light therapy for postpartum depression. Arch Womens Ment Health., 10:221-4.

7. De Crescenzo F, Perelli F, Armando M, Vicari S. (2014) Selective serotonin reuptake inhibitors (SSRIs) for post-partum depression (PPD): a systematic review of randomized clinical trials. J Affect Disord., 152-4:39-44.

8. Dennis CL, Dowswell T.(2013) Psychosocial and psychological interventions for preventing postpartum depression. Cochrane Database Syst Rev., 2:CD001134.

9. di Scalea TL, Wisner KL.(2009) Pharmacotherapy of postpartum depression. Expert Opin Pharmacother., 10:2593-607.

10. Freeman MP, Davis M, Sinha P, Wisner KL, Hibbeln JR, Gelenberg AJ.(2008) Omega-3 fatty acids and supportive psychotherapy for perinatal depression: a randomized placebo-controlled study. J Affect Disord., 110:142-8.

11. Gavin NI, Gaynes BN, Lohr KN, Meltzer-Brody S, Gartlehner G, Swinson T.(2005) Perinatal depression: A systematic review of prevalence and incidence Obstetrics and Gynecology., 106(5pt1):1071-83

12. Gentile S, Galbally M.(2011) Prenatal exposure to antidepressant medications and neurodevelopmental outcomes: a systematic review. J Affect Disord., 128:1-9.

13. Glynn LM, Davis EP, Sandman CA. (2013) New insights into the role of perinatal HPA-axis dysregulation in postpartum depression. Neuropeptides., 47:363-70. 
14. Goodman JH, Santangelo G.(2011) Group treatment for postpartum depression: a systematic review. Arch Womens Ment Health., 14:277-93.

15. Green K, Broome H, Mirabella J.(2006) Postnatal depression among mothers in the United Arab Emirates: socio-cultural and physical factors. Psychol Health Med., 11:425-31 22.

16. Gregoire AJ, Kumar R, Everitt B, Henderson AF, Studd JW. (1996)Transdermal oestrogen for treatment of severe postnatal depression. Lancet., 347(9006):930-3.

17. Jarde A, Morais M, Kingston D, Giallo R, MacQueen GM, Giglia L, et al.(2016) Neonatal Outcomes in Women With Untreated Antenatal Depression Compared With Women Without Depression: A Systematic Review and Meta-analysis. JAMA Psychiatry.

18. Jeste V. (2013): American Psychiatric Association. Diagnostic and statistical manual of mental disorders. 5th edition. American Psychiatric Publishing; Arlington; VA; pp.152.

19. Kashani L, Eslatmanesh S, Saedi N, Niroomand N, Ebrahimi M, Hosseinian M et al.(2017) Comparison of Saffron versus Fluoxetine in Treatment of Mild to Moderate Postpartum Depression: A Double Blind, Randomized Clinical Trial. Pharmacopsychiatry., 50:64-8.

20. Kim DR, Epperson CN, Weiss AR, Wisner KL.(2014) Pharmacotherapy of postpartum depression: an update. Expert Opin Pharmacother., 15:1223-34.

21. Kim DR, Pinheiro E, Luther JF, Eng HF, Dills JL, Wisniewski SR et al.(2016) Is third trimester serotonin reuptake inhibitor use associated with postpartum haemorrhage? J Psychiatr Res., 73:79-85.

22. Kinser P, Masho S.(2015) "Yoga Was My Saving Grace": The Experience of Women Who Practice Prenatal Yoga. J Am Psychiatr Nurses Assoc., 21:319-26.

23. Lau Y, Htun TP, Wong SN, Tam WSW, Klainin-Yobas P.(2017) Therapist-Supported Internet-Based Cognitive Behavior Therapy for Stress, Anxiety, and Depressive Symptoms Among Postpartum Women: A Systematic Review and Meta-Analysis. J Med Internet Res.,19:e138.

24. Lawrie TA, Hofmeyr GJ, De Jager M, Berk M, Paiker J, Viljoen E.(1998) A double-blind randomised placebo controlled trial of postnatal norethisterone enanthate: the effect on postnatal depression and serum hormones. $\mathrm{Br}$ J Obstet Gynaecol., 105:1082-90.

25. Leis JA, Mendelson T, Tandon SD, Perry DF.(2009) A systematic review of home-based interventions to prevent and treat postpartum depression. Arch Womens Ment Health.,12:3-28.

26. Makrides M.(2012) Oily fish and omega-3 fatty acids: what is the effect size? European Psychiatry., $27: 1$.

27. McCurdy AP, Boulé NG, Sivak A. (2017) Davenport MH. Effects of Exercise on Mild-to-Moderate Depressive Symptoms in the Postpartum Period: A Meta-analysis. Obstet Gynecol., 129:1087-97.

28. Mendelson T, Cluxton-Keller F, Vullo GC, Tandon SD, Noazin S. (2017) NICU-based Interventions To Reduce Maternal Depressive and Anxiety Symptoms: A Meta-analysis. Pediatrics., 139. pii: e20161870.

29. Miller BJ, Murray L, Beckmann MM, Kent T, Macfarlane B.(2013) Dietary supplements for preventing postnatal depression. Cochrane Database Syst Rev., 10:CD009104.

30. Miniati M, Callari A, Calugi S, Rucci P, Savino M, Mauri M et al. (2014) Interpersonal psychotherapy for postpartum depression: a systematic review. Arch Womens Ment Health., 17:257-68.

31. Moses-Kolko EL, Wisner KL, Price JC, Berga SL, Drevets WC, Hanusa BH et al.(2008) Serotonin 1A receptor reductions in postpartum depression: a positron emission tomography study. Fertil Steril. 89:685-92.

32. Mozurkewich EL, Clinton CM, Chilimigras JL, Hamilton SE, Allbaugh LJ, Berman DR et al.(2013) The Mothers, Omega-3, and Mental Health Study: a double blind, randomized controlled trial. Am J Obstet Gynecol., 208:313.e1-9.

33. Ng RC, Hirata CK, Yeung W, Haller E, Finley PR. (2010) Pharmacologic treatment for postpartum depression: a systematic review. Pharmacotherapy., 30:928-41.

34. O’Hara M, Gorman LL. (2004) Can postpartum depression be predicted? Primary Psychiatry., 11:42-7

35. Osborne L, Clive M, Kimmel M, Gispen F, Guintivano J, Brown T et al. (2016) Replication of Epigenetic Postpartum Depression Biomarkers and Variation with Hormone Levels. Neuropsychopharmacology., 41:164858.

36. Rojas G, Fritsch R, Solis J, Jadresic E, Castillo C, González M et al. (2007)Treatment of postnatal depression in low-income mothers in primary-care clinics in Santiago, Chile: a randomized controlled trial. Lancet., 370:1629-37.

37. Schiller CE, Meltzer-Brody S, Rubinow DR. (2015) The role of reproductive hormones in postpartum depression. CNS Spectr., 20:48-59.

38. Sockol LE, Epperson CN, Barber JP. (2013) Preventing postpartum depression: a meta-analytic review. Clin Psychol Rev., 33:1205-17. 
39. Sockol LE. (2015)A systematic review of the efficacy of cognitive behavioral therapy for treating and preventing perinatal depression. J Affect Disord., 177:7-21.

40. Stuart-Parrigon (2014) American College of Obstetrics and Gynecology. [cited 2014 March 27, 2014] Screening for Depression During and After Pregnancy. 2010. Available from:http://www.acog.org/Resources_And_Publications/Committee_Opinions/Committee_on_Obstetric_Practi ce/Screening_for_Depression_During_and_After_Pregnancy

41. Underwood L, Waldie KE, Peterson E, D'Souza S, Verbiest M, McDaid F et al. (2017) Paternal Depression Symptoms During pregnancy and after childbirth among participants in the growing up in New Zealand study. JAMA Psychiatry., 74:1-10.

42. Vaziri F, Nasiri S, Tavana Z, Dabbaghmanesh MH, Sharif F, Jafari P. (2016) A randomized controlled trial of vitamin D supplementation on perinatal depression: in Iranian pregnant mothers. BMC Pregnancy Childbirth., 16: 239. doi: 10.1186/s12884-016-1024-7.

43. Wang S, Yang L, Wang L, Gao L, Xu B, Xiong Y. (2015) Selective Serotonin Reuptake Inhibitors (SSRIs) and the Risk of Congenital Heart Defects: A Meta-Analysis of Prospective Cohort Studies. J Am Heart Assoc., 4. pii: e001681

44. Werner E, Miller M, Osborne LM, Kuzava S, Monk C. (2015) Preventing postpartum depression: review and recommendations. Arch Womens Ment Health., 18:41-60.

45. Wirz-Justice A, Bader A, Frisch U, Stieglitz RD, Alder J, Bitzer J et al. (2011) A randomized, double-blind, placebo-controlled study of light therapy for antepartum depression. J Clin Psychiatry., 72:986-93.

46. Wisner KL, Perel JM, Peindl KS, Hanusa BH, Piontek CM, Findling RL. (2004) Prevention of postpartum depression: a pilot randomized clinical trial. Am J Psychiatry., 161:1290-2.

47. Wisner KL, Sit DK, Moses-Kolko EL, Driscoll KE, Prairie BA, Stika CS et al. (2015) Transdermal Estradiol Treatment for Postpartum Depression: A Pilot Randomized Trial. J Clin Psychopharmacol.,35:389-95.

48. Yonkers KA, Lin H, Howell HB, Heath AC, Cohen LS. (2008) Pharmacologic treatment of postpartum women with new-onset major depressive disorder: a randomized controlled trial with paroxetine. J Clin Psychiatry., 69:659-65. 